\title{
THE IMPACT OF NATIONAL ECONOMY STRUCTURAL TRANSFORMATION ON REGIONAL EMPLOYMENT AND INCOME: THE CASE OF LATVIA
}

Aleksandra Mihnenoka, Maija Senfelde

\begin{abstract}
Structural changes taking place in national and regional economy may vary across nations and regions, causing socio-economic differentiation. This research is focused on analysis of the employment structure, its changes and influence on the level of social welfare, and its deepening of economic disparities between Latvian regions. We apply a comparative statistical analysis based on two tools: the Location Quotient and shift-share analysis, using official Latvian statistical data on employment and income with a breakdown by ten groups of economic activities for the period from 2008 to 2016. The obtained results indicate that the changes in the employment structure during the studied period had a noticeable impact on regional differentiation in Latvia. The authors have discovered that although employment concentration varies across Latvian regions, it remains remarkably stable over time, with occasional re-employment shifts occurring not always in the direction of industries providing higher income, which causes further regional socio-economic differentiation in Latvia.
\end{abstract}

Keywords: regional economics; employment structure; income; structural changes; comparative analysis; location quotient.

JEL classification: $J 21, J 31, R 11$

\section{INTRODUCTION}

The balanced development of all regions is vital for the sustainable growth of each country and the prosperity of its population. Nevertheless, each country faces various obstacles connected with the different types of disparities that prevent it from reaching these goals. Latvia has been an independent country for twenty-five years, and for more than ten years it has been a member-state of the European Union. During this period, Latvia has undergone considerable changes on its way of development and growth. The first decade of the reestablishment of independence was marked by extensive economic, social and political changes in the process of sustainable growth and social well-being. These changes also affected territorial division within the country. The territory of Latvia is divided into the following six statistical regions: Riga, Pieriga, Vidzeme, Kurzeme, Zemgale, and Latgale.

Latvia and its statistical regions still face various challenges. One of the factors impeding the economic

\section{Aleksandra Mihnenoka}

Riga Technical University, Faculty of Engineering Economics and Management,

E-mail: aleksandra.mihnenoka@rtu.Iv

\section{Maija Senfelde}

Riga Technical University, Faculty of Engineering Economics and Management

E-mail: maija.senfelde@rtu.Iv 
development of Latvia is the high regional differentiation between the Riga region and other regions of the country (Central Statistical Bureau of Latvia, 2017). Although there is some evidence of convergence at the national level for EU countries, in most cases regional convergence within countries is not observed, especially in Latvia, where the level of divergence between regions is persistent over time and remains one of the highest across the $\mathrm{EU}$, including the other two Baltic countries (Mikulić, Lovrinčević, and Nagyszombaty 2013; Melihovs and Kasjanovs 2011). However, there has not been any recent research that has studied regional differentiation in Latvia.

Moreover, the process of structural changes, in terms of output and employment distribution between different types of economic activity, takes place not only at the national level, but also affects the structure of regional economies. As has been claimed, structural changes do not contribute in all cases to rapid economic growth (McMillan, Rodrik, and Sepúlveda 2016). Unfortunately, in the case of Latvia there have not been any recent studies that would link the process of structural changes with regional differentiation through the analysis of changes in employment distribution and income.

The case of Latvia is important for research because it had the highest rates of GDP growth among EU member states before the economic crisis of 20082010 , which was followed by the deepest downturn within the EU as the overall GDP decreased by $21.3 \%$ (Skribane and Jekabsone 2013). Therefore, the goal of this research is to analyze the changes in the employment structure and income across ten groups of economic activity in Latvian statistical regions and to find out whether the changes in the employment structure have any impact on regional socio-economic differentiation. To conduct the research, we applied a comparative statistical analysis for the period of 2008-2016.

The structure of the research is organized as follows: First, we define the types of economic activity in terms of employment in which a certain statistical region specializes, applying the Location Quotiet as a tool for this part of our research. Second, we analyze the impact of the changes in the employment structure on the changes in income across Latvian regions, applying the breakdown of income changes. Third, we compare the level of income in a certain type of economic activity with the average income in a certain region and with the average income at the national level in a particular type of economic activity. Finally, we draw a conclusion on the revealed specialization of certain regions and their existing employment structure, and whether the changes in it contribute to the development of the corresoponding region.

\section{THEORETICAL BACKGROUND}

\subsection{Aspects of regional disparities}

Regarding regional disparities within one country or between multiple countries, Wishlade and Yuill (1997) and other authors (Tvrdoň and Skokan 2011; Kutscherauer et al. 2010) distinguish and apply for analysis three types of disparities - physical, economic and social disparities. However, a precise assignment of factors to each particular type of disparity has not yet been developed.

According to Wishlade and Yuill (1997), the following factors characterize the relevant types of disparities:

- Territorial or physical disparities are used to estimate the natural environment of a certain territory with its advantages and disadvantages. These indicators mostly aim to evaluate climate conditions and environment, the development and availability of infrastructure, population density and its changes over time;

- Economic disparities refer to the economic potential of the region and its possibility to contribute to employment, with added consideration given to the structure of the economy. The most well-known and traditional indicator for the aforementioned purposes is GDP per capita. Moreover, the evaluation of the economic situation in the region also incorporates the analysis of tax revenues, transport facilities and demographic trends;

- Social disparities relate to the level of income and standards of living, with a focus on employment indicators, i.e. unemployment and its structure, employment trends, etc.

Many authors have studied social and economic challenges to an economy and resulting socio-economic disparities. For example, Kutscherauer et al. (2010) apply a three-type division of regional disparities and factor assignment similar to the one described above, while for economic factors they use an analysis of employment beyond the previously mentioned indicators. For example, the most frequently applied indicators within the EU regarding economic disparities are GDP per capita and disposable income. To assess social differences, employment and unemployment rates are applied, as well as indicators related to tertiary education (Poledníková and Lelková 2012). The economists suggest that income and employment have an impact on social as well as economic disparities within a country - social well-being depends on people's employment status and the level of their income. Higher employment rates and income levels are tied to higher living standards and greater potential growth. Therefore, it is necessary to analyze 
income (wages, salaries, and other types of remuneration that represent a considerable part of workforce income, and consequently disposable income) and its changes in Latvia and statistical regions to disclose the aforementioned disparities.

\subsection{Structural changes and specialization}

In addition to research on income, currently economists are also concerned with the structure of the national economy, because this structure affects the potential for national development. As Stiglitz notes (Stiglitz 2011), structural changes in a national economy have a considerable effect on the development of a sustainable economic strategy.

The process of structural changes has attracted economists` attention for a long time and is still discussed in the literature, as well as in in the context of Latvia (Skribane and Jekabsone 2013; Šipilova and Baldi 2013; Mihnenoka and Saulītis 2013). Structural changes in a national economy also imply changes in the sectoral composition of output and employment. Clark (1940) proposes the most applicable and traditional division of the national economy - he distinguishes three sectors of the national economy: agriculture, industry and services or the primary, secondary and tertiary sectors. In addition, Fisher (1939), Wolfe (1955), Fourastie (1954) and others have also made a considerable contribution to the explanation of the sectoral division of a national economy and its changes Kruger (2008), Silva and Teixera (2008) have summarized the theoretical aspects of structural economic changes. For instance, Fourastié, Fisher and Clark claim that during the process of economic development, employment first shifts from agriculture to manufacturing and then to services. This is the core aspect of the three-sector hypothesis.

Kuznets (1973) has made a significant contribution to the research on economic growth and interpretation of the process of structural changes. He has discovered the relationship between an increase in GDP level per capita and a shift in the structure of consumption. He states that, among other factors, technological progress is the primary source of economic growth and structural changes. In addition, there is some evidence that aggregate economic growth causes structural changes, as well as the other way round (Dietrich 2012). All of this points to the necessity for the planned development of a national economy's structure.

The rise of the tertiary sector, especially knowledge-based services, is a predominant pattern of structural changes in most countries today (Wölfl
2005). In addition, it is widely known that manufacturing contributes to national development and regional development (Stojčić, Bezić, and Galović 2016). Therefore, concerns regarding the decrease of manufacturing share and the necessity of reindustrialization at the national and regional level routinely appear. Moreover, Wolfi (2005) points out that services and manufacturing interact with each other, which may be beneficial for all industries. For example, the transitional period in Latvia since the reestablishment of independence was also characterized by large shifts in the sectoral composition of output and employment (Havlik 2005; Šipilova 2012) towards the adjustment to developed economies, reducing the shares of the primary and secondary sectors and increasing the importance of the tertiary sector.

Therefore, attention to the driving forces behind these changes and development is also increasing ( Peneder, Kaniovski, and Dachs 2003; Peneder 2009). Moreover, in terms of output and employment distribution, sectoral structure is an additional factor that influences, affects and provokes regional differentiation (Šipilova 2013; Šipilova and Baldi 2013). In addition, O'Leary and Webber (2015) claim that the reallocation of workforces between and within sectors has a positive impact on productivity growth at the national and regional levels, increasing the income of employees. However, the researchers admit that structural changes for richer regions promote divergence, while structural changes implemented for relatively poor regions that are falling behind the average growth pace may contribute to convergence to the average (O'Leary and Webber 2015).

Moreover, the investigation of the economic specialization of regions and/or countries is becoming increasingly topical among researchers in the world (MPS Task Force of the ESCB 2004; Kemeny and Storper 2015) and especially in Latvia (Šipilova and Baldi 2013), as the structure of the national economy has been significantly reshaped after the reestablishment of independence and the transition to a market economy. Consequently, regional specialization and the concentration of certain types of economic activities in these regions are important factors that may also affect regional disparities I (Makarem, Storper, and Kemeny 2015).

\section{RESEARCH DATA AND METHOD}

The structure of a national as well as regional economies can be studied from the vantage of GDP and employment distribution, with a breakdown by sectors and/or a broader division by types of economic 
activity, while the income of employees is a significant indicator for the study of socio-economic disparities. Therefore, we applied a comparative statistical method to analyze changes in employment structure and income occurring during the years 2008-2016, and to reveal the impact of the structural changes on social welfare across Latvian regions.

The research data were compiled from the Central Statistical Bureau of Latvia (2017). The choice of the period from 2008-2010 was based on the assumption that the year 2008 was the last year prior to the economic downturn, which caused considerable structural changes in the economy of Latvia, while reliable statistical data were available only till 2015/2016 (we used the last available data). The data comprise the following indicators for six statistical regions of Latvia and for the country as a whole: the number of employees and the average monthly income in economic activities based on NACE 2. Rev. division; and data on income, including basic wages and salaries, all remunerations, bonuses, compensations, employees` social security compulsory contributions and personal income tax. The data are analyzed for the following six statistical regions of Latvia: Riga, Pieriga, Vidzeme, Kurzeme, Zemgale, and Latgale.

First, the structures of national as well as regional economies were divided into ten groups of economic activities: agriculture, forestry and fishing (A); manufacturing, mining, quarrying, and power engineering (B-E); construction (F); trade, hospitality and catering s $(\mathrm{G}, \mathrm{l})$; transportation and storage, and information and communication technologies (ICT) $(\mathrm{H}, \mathrm{J})$; financial, insurance, scientific, administrative and real estate (K-N); public administration, defence, and compulsory social security $(O)$; education $(P)$; human health and social work (Q); other services such as arts, entertainment, recreation and others (R-U). Hereinafter the authors use the aforementioned abbreviations for types of economic activities.

Second, we aggregated and sorted the data on average monthly income from nineteen economic activities to ten groups of economic activities using the method of a simple average, because the employment data for regional purposes had been already provided in the breakdown by ten branches. Furthermore, the authors calculated the real income adjusted for inflation using Consumer Price Indices with the reference period $2010=100$.

Finally, to conduct the research the authors applied the following tools: Location Quotient and breakdown of income change.

\subsection{Location Quotient}

To identify regional specialization in terms of employment distribution between industries (10 groups of economic activities) within a certain region, the authors used Location Quotient (LQ), which is similar to the Balassa index. Researchers widely apply it to make an assessment of area composition (MPS Task Force of the ESCB 2004; Gokan 2010; Šipilova and Baldi 2013; Fracasso and Vittucci Marzetti 2017). It is defined as follows:

$$
L Q=\left(\frac{E_{j}^{i}}{E_{C}^{i}}\right) \div\left(\frac{E_{j}}{E_{C}}\right)
$$

In Formula 1, LQ is Location Quotient, which reveals local preferences regarding the aggregate area. The following notation is used. LQ is a Location Quotient for an industry (a type of economic activity) $i$ in a region $j . E$ is an employment; however, in other cases instead of data on employees data on value added or even income can be used. The subscript $i, j$, and $c$ identify a type of economic activity, a region, and the whole country respectively.

The first part of Formula 1, the dividend, displays a regional percentage share of a certain activity, in other words, the share of employees that are engaged in a certain activity within this region. The divider in Formula 1 represents the share of employees that are engaged in a certain activity within the whole country. The values of LQ are interpreted as follows (Dinc 2002; Gokan 2010):

- If LQ takes values higher than 1, this indicates a regional comparative advantage of a region $j$ in a type of economic activity $i$ relative to the reference country $c$. That is, in region $j$ in economic activity $i$ relatively more people are employed than in country $c$ as a whole;

- If an LQ is equal to 1, a type of activity $i$ has the same share of employment in a region $R$ as it does in the reference area $c$;

- If an LQ is less than 1, that implies that the share of regional employment $j$ is smaller than the share of national employment $c$ in the same activity $i$.

According to Sayago-Gomez and Stair (2015), LQs of economic activities are basically used to define the industries that either make a regional economy unique or are not appealing to employees, as well as to identify the most export-oriented industries and still developing activities in the region. Implementation of the LQ tool makes it possible to map spatial patterns of industrial concentration, while the investigation of changes in LQs provides useful information on whether each type of economic activity is increasing or 
decreasing its concentration and importance in a local area relative to other areas (Dinc 2002). Economic activities that compose specialization contribute to the growth of exports and increase the level of employment. Therefore, the LQ tool is applicable for both national and regional policymaking purposes to facilitate economic growth and development of this area. For the case of Latvia, the results of LQ value measurement are presented in Subsection 4.1.

\subsection{Decomposition of income changes}

Regarding the decomposition of changes in income, the authors implemented the "shift-share analysis" adjusted to the evaluation of the changes in income of employees, considering the impact of changes in employment shares. This method is proposed by Keller (2009); however, in this study we used it with some modifications in order to reveal how the average level of income in Latvian statistical regions has changed due to employment shifts between economic activities. Instead of occupational division, the method was used in terms of employment distribution, applying a breakdown by 10 types of economic activity, i.e. decomposition was made not for the national but for the regional level.

Assuming that the change in the real average income in a certain region depends on three components (Keller 2009) - a regional income component, a regional employment component and a regional residual component, the authors use the following mathematical notation to describe the decomposition:

$$
\begin{gathered}
\overline{w_{t+1}}-\overline{w_{t}}=\overline{w_{t+1}}-\overline{w_{t}}= \\
\underbrace{\sum_{i=1}^{i}\left(\frac{E_{i}}{E}\right)_{t} \Delta \bar{w}_{i}}_{\begin{array}{c}
\text { Regional income } \\
\text { component }
\end{array}}+\underbrace{\sum_{i=1}^{i} \bar{w}_{i t} \Delta\left(\frac{E_{i}}{E}\right)}_{\begin{array}{c}
\text { Regional employment } \\
\text { component }
\end{array}}+\underbrace{\sum_{i=1}^{i} \Delta \bar{w}_{i} \Delta\left(\frac{E_{i}}{E}\right),}_{\begin{array}{c}
\text { Regional residual } \\
\text { component }
\end{array}}
\end{gathered}
$$

where:

$i$ - a type of economic activity, in a total 10 groups of the aggregated branches, (A-U),

$\Delta \quad$ - change from 2008 to 2016,

$\bar{w} \quad$ - real average income of a certain region,

$\overline{w_{i}}$ - real average income in an economic activity $i$ within a certain region,

$E$ - number of employees in a region,

$E_{i} \quad$ - number of employees in an economic activity $i$ in a certain region,

$t$ - the year 2008,

$t+1 \quad$ - the year 2016 .
The first constituent of Formula 2 is the regional income component. It displays the contribution of changes in income of the particular economic activity to the changes in the regional average income. If this component is positive, this indicates that the mean income in a particular economic activity has increased during the research period, while a negative result indicates a decrease.

The regional employment component, the second constituent of Formula 2, represents the contribution of changes in the employment structure to the changes in average regional income level. If this component is positive, the employment share increased during the research period, but the negative component indicates the opposite result.

The third component of Formula 2, the residual, captures the joint effect of changes in employment share and income, though it is not solely attributed neither to the employment effect nor to the income component. Therefore, in terms of this research, it is less significant.

The sum of all three components for all economic activities represents the change in the real average income in a certain region. For the case of Latvia, the results of the breakdown in income changes are presented in Subsection 4.2.

\section{RESULTS AND DISCUSSION}

\subsection{Employment specialization in Latvian regions}

Table 1 presents the results of Location Quotient calculations for 2016 (Column 2); its percentage changes from 2008 to 2016 (Column 3) and employment share (Column 4) varies by the type of economic activity (Column 1) in Latvian statistical regions. The highest values of LQ in 2016 are marked out in bold in Columns 1 and 2 . The results in Table 1 are based on the authors' calculations, using the statistical data compiled from the Central Statistical Bureau of Latvia on the number of employees with a breakdown by the type of economic activity and region.

The results of this analysis not only display the trends in employment specialization, i.e. employment concentration and its change in regions, but also reveal that regions do not perform equally. Furthermore, it becomes evident that there are several types of economic activities, which are typical of the Latvian national economy. 
Table 1. Location Quotients and employment shares (\%) by the type of economic activity and statistical region of Latvia, in 2016

\begin{tabular}{|c|c|c|c|}
\hline $\begin{array}{l}\text { Type of } \\
\text { activity }\end{array}$ & $\begin{array}{c}\text { LQ } \\
2016\end{array}$ & $\begin{array}{c}\Delta \mathrm{LQ} \text { from } \\
2008 \text { to } \\
2016(\%)\end{array}$ & $\begin{array}{c}\text { Employment share } \\
\text { in activity } \boldsymbol{i} \text { in } \\
\text { region } \boldsymbol{j}(\%)\end{array}$ \\
\hline 1 & 2 & 3 & 4 \\
\hline \multicolumn{4}{|c|}{ Riga region } \\
\hline$(\mathrm{A})$ & 0.09 & 97.0 & 0.7 \\
\hline (B-E) & 0.83 & -14.2 & 12.9 \\
\hline$(\mathrm{F})$ & 0.84 & -18.4 & 6.8 \\
\hline$(G, I)$ & 1.12 & -5.0 & 19.9 \\
\hline$(H, J)$ & 1.32 & 0.9 & 16.4 \\
\hline$(\mathrm{K}-\mathrm{N})$ & 1.57 & 1.7 & 17.9 \\
\hline (O) & 0.87 & 3.5 & 5.7 \\
\hline$(\mathrm{P})$ & 0.89 & 11.4 & 8.3 \\
\hline (Q) & 1.00 & 2.6 & 6.2 \\
\hline$(R-U)$ & 1.14 & 10.4 & 5.3 \\
\hline \multicolumn{4}{|c|}{ Pieriga region } \\
\hline$(\mathrm{A})$ & 0.96 & 2.7 & 7.6 \\
\hline$(B-E)$ & 1.08 & 14.7 & 16.8 \\
\hline$(F)$ & 1.11 & 5.7 & 8.9 \\
\hline$(G, I)$ & 1.04 & -8.0 & 18.5 \\
\hline$(\mathrm{H}, \mathrm{J})$ & 0.90 & 9.8 & 11.2 \\
\hline$(\mathrm{K}-\mathrm{N})$ & 0.97 & 5.7 & 11.1 \\
\hline$(\mathrm{O})$ & 1.04 & 6.1 & 6.9 \\
\hline$(\mathrm{P})$ & 0.91 & -10.9 & 8.4 \\
\hline (Q) & 0.84 & -16.9 & 5.2 \\
\hline$(R-U)$ & 1.13 & -7.2 & 5.2 \\
\hline \multicolumn{4}{|c|}{ Vidzeme region } \\
\hline (A) & 2.11 & 0.0 & 7.6 \\
\hline$(B-E)$ & 1.06 & 18.8 & 16.8 \\
\hline (F) & 1.26 & 35.1 & 8.9 \\
\hline$(G, I)$ & 0.81 & -15.9 & 18.5 \\
\hline$(\mathrm{H}, \mathrm{J})$ & 0.62 & -5.1 & 11.2 \\
\hline$(\mathrm{K}-\mathrm{N})$ & 0.44 & -42.9 & 11.1 \\
\hline (O) & 1.10 & 13.9 & 6.9 \\
\hline$(\mathrm{P})$ & 1.15 & 2.4 & 8.4 \\
\hline (Q) & 1.13 & 15.8 & 5.2 \\
\hline$(\mathrm{R}-\mathrm{U})$ & 0.91 & 9.9 & 5.2 \\
\hline
\end{tabular}

\begin{tabular}{|c|c|c|c|}
\hline $\begin{array}{l}\text { Type of } \\
\text { activity }\end{array}$ & $\begin{array}{c}\text { LQ } \\
2016\end{array}$ & $\begin{array}{l}\Delta L Q \text { from } \\
2008 \text { to } \\
2016(\%)\end{array}$ & $\begin{array}{l}\text { Employment share } \\
\text { in activity } \boldsymbol{i} \text { in } \\
\text { region } \boldsymbol{j}(\%)\end{array}$ \\
\hline 1 & 2 & 3 & 4 \\
\hline \multicolumn{4}{|c|}{ Kurzeme region } \\
\hline (A) & 1.48 & -12.7 & 11.8 \\
\hline (B-E) & 1.22 & -3.8 & 19.0 \\
\hline$(F)$ & 1.12 & 32.9 & 9.0 \\
\hline$(G, I)$ & 0.91 & 32.8 & 16.1 \\
\hline$(\mathrm{H}, \mathrm{J})$ & 0.97 & -5.9 & 12.1 \\
\hline$(\mathrm{K}-\mathrm{N})$ & 0.57 & -3.3 & 6.6 \\
\hline (O) & 0.89 & -12.1 & 5.9 \\
\hline (P) & 1.08 & -4.9 & 10.0 \\
\hline (Q) & 0.87 & 1.2 & 5.4 \\
\hline$(\mathrm{R}-\mathrm{U})$ & 0.89 & -7.1 & 4.1 \\
\hline \multicolumn{4}{|c|}{ Zemgale region } \\
\hline (A) & 1.72 & 24.1 & 13.7 \\
\hline$(B-E)$ & 1.12 & 16.3 & 17.4 \\
\hline$(\mathrm{F})$ & 1.05 & -14.5 & 8.4 \\
\hline$(G, I)$ & 1.00 & 2.9 & 17.7 \\
\hline$(\mathrm{H}, \mathrm{J})$ & 0.76 & 5.2 & 9.4 \\
\hline$(\mathrm{K}-\mathrm{N})$ & 0.63 & -15.6 & 7.2 \\
\hline$(\mathrm{O})$ & 1.10 & 0.8 & 7.3 \\
\hline (P) & 1.00 & -1.6 & 9.3 \\
\hline (Q) & 1.03 & 14.7 & 6.4 \\
\hline$(R-U)$ & 0.68 & -34.1 & 3.2 \\
\hline \multicolumn{4}{|c|}{ Latgale region } \\
\hline (A) & 1.65 & -4.8 & 13.1 \\
\hline (B-E) & 1.00 & -2.6 & 15.6 \\
\hline$(\mathrm{F})$ & 0.90 & 6.0 & 7.2 \\
\hline$(G, I)$ & 0.84 & 12.7 & 15.0 \\
\hline$(\mathrm{H}, \mathrm{J})$ & 0.80 & -11.2 & 10.0 \\
\hline$(\mathrm{K}-\mathrm{N})$ & 0.63 & 24.3 & 7.2 \\
\hline (0) & 1.23 & -8.6 & 8.1 \\
\hline (P) & 1.28 & 1.6 & 11.9 \\
\hline (Q) & 1.25 & -2.6 & 7.8 \\
\hline$(\mathrm{R}-\mathrm{U})$ & 0.89 & 14.3 & 4.2 \\
\hline
\end{tabular}

Source of raw data for authors`calculations: Central Statistical Bureau of Latvia (accessed in 2017)

Regarding the data in Table 1, the Riga region distinctly specializes in four groups of economic activities - trade and related activities $(G, I)$, transportation, storage and ICT $(\mathrm{H}, \mathrm{J})$, financial activities $(\mathrm{K}-\mathrm{N})$, and other services (R-U). In the Riga region, these industries, except other services $(R-U)$, engage the highest shares of employees in comparison with the other activities in the region $-19.9 \%, 16.4 \%$ and $17.9 \%$ of employees, respectively.

During the research period, the Riga region increased its employment specialization (change of LQ) in almost all activities, except industry and power engineering (B-E) and construction ( $\mathrm{F})$, which declined by $14.2 \%$ and $18.4 \%$, respectively. Specialization in the Riga region can be explained by the high economic activity of the region: it is the capital of Latvia and its financial and communications center, which contributes to the whole country.

The Pieriga region does not stand out in terms of any type of economic activity regarding employment concentration in comparison with other regions. However, in terms of regional importance, it can be stated that Pieriga has LQ values close to specialization in industry and power engineering (B-E), construction ( $F$ ) and other services (R-U). Furthermore, the Pieriga region has the lowest dispersion of $L Q$ values - the concentration of employees in the sectors of economic activities is rather similar to the national distribution. 
In comparison with other regions, the Vidzeme region strongly specializes in agriculture $(\mathrm{LQ}=2.11)$ and construction $(\mathrm{F})$; the latter specialisation has increased by $35.1 \%$ since 2008 . However, the highest employment shares in the region are in industry, power engineering (B-E) and trade, hospitality and catering activities $(\mathrm{G}, \mathrm{l})$; these comprise $16.8 \%$ and $18.5 \%$ of employment, respectively.

The Kurzeme region, similarly to Vidzeme, has the highest employment shares in industry and power engineering ( $B-E)$ and trade, hospitality and catering related activities $(G, I)$, but its highest level of specialisation nationally is in industry and power engineering sector ( $L Q=1.22)$. In terms of regional importance, agriculture and construction, where employment specialization has increased the most during the research period, can also be marked as significant relative to other regions.

The Zemgale region is similar to Pieriga and has no obvious employment specialization. However, since 2008 it has displayed an increase in employment concentration in agriculture (by $24.1 \%$ to $L Q=1.48$ ). There is also the highest share of employees in the primary sector in comparison with other regions, while high $L Q$ values are also marked in agriculture $(A)$, industry and power engineering (B-E), which form relative advantages for this region.

The Latgale region stands out with its employment concentration in the following activities: public administration, defence and compulsory social security $(\mathrm{O})$, education $(\mathrm{P})$, and human health and social work activities $(\mathrm{Q})$, as well as agriculture $(\mathrm{A})$, which makes for a relative advantage in terms of the regional specialisation. High employment specialization in the aforementioned industries may be explained by the underdevelopment of the region. On the one hand, the Latgale region is the least developed region in Latvia, with the highest unemployment rates (Crosssectoral Coordination Centre 2013). On the other hand, it has the highest decrease in the number of inhabitants - on average by $2.08 \%$ per year, while in Latvia on average it is $1.21 \%$; furthermore, in the Latgale region, there is the highest share of elderly people and the lowest share of people under working age (Kamola, Ivanova, and Kamols 2016). Such a situation and the government attempts to mitigate its negative effects resulted in the necessity of different types of health and social work activities. Regarding education, the Latgale region, specifically the city of Daugavpils, is the location of Daugavpils University, one of the notable universities in Latvia, and which attracts students not only from Latgale but from other regions and countries. This increases the number of people employed in education.
In general, the relative employment specialization of Latvian regions, in terms of employment concentration, varies according to the type of economic activities. However, agriculture (A) exists as an employment specialization in most Latvian regions, except Riga and Pieriga. The Riga region stands distinctly ahead of other regions with the highest rates of employment specialization in finance, trade and transportation-related activities. Furthermore, these spheres, especially trade-related activities, employ a significant share of the workforce. Industry and power engineering (B$\mathrm{E})$ in the Pieriga, Kurzeme and Zemgale regions, and construction ( $F$ ) in the Pieriga, Kurzeme, and Vidzeme regions, also show employment specialization.

In addition, comparing our results with the results of Vanags, Basarova and Titova (2002) obtained about 15 years ago, we can conclude that the Riga region has maintained its major positions in the activities related to trade, hospitality and catering, finances and real estate, while it has lost its status as a manufacturing center because many factories and plants in Riga were closed during the transition period. Although the previous research results showed that the primary sector was more developed in Zemgale and Kurzeme, and to a lesser extent in Vidzeme, our research demonstrates that agriculture-related activities are also substantially represented in almost all regions, with the highest concentration in Vidzeme. The number of activities related to manufacturing, mining, quarrying and power engineering is especially high in Vidzeme, as well as in Zemgale and Latgale, which specialize in these activities, but recently Kurzeme has moved distinctly ahead. On the other hand, Kurzeme specialized in construction, while recently this industry has become typical not only of the Kurzeme region, but also of Vidzeme (to a greater degree), Zemgale and Pieriga. At the end of the nineties, public activities related to administration, medicine, education, etc., were the mostly localized in Latgale, Vidzeme and Zemgale. Currently, the localization of these activities remains the same, with a noticeable predominance of Latgale. Overall, the employment specialization of Latvian regions remains relatively permanent, with some noticeable changes in levels of concentration. Vanags, Basarova, and Titova (2002) provide a comparison of three Baltic countries and report that, in contrast to both Estonia and Latvia, in Lithuania any growth aureole around its capital Vilnius is not created, while economic activities at the national level are distributed rather evenly, where the differences between agricultural and heavily industrialized regions are clearly noted (Vanags, Basarova, and Titova 2002, 26).

Moreover, the observed changes in the degree of employment concentration $(\Delta \mathrm{LQ})$ in different types of 
economic activity prove that the spatial localization of economic activities in Latvia is not a constant value but a dynamically developing indicator (Boronenko and Zeibote 2011, 49), and the results of this paper (Table 1, LQ level changes) are in line with this statement.

Other researchers (Boronenko and Zeibote 2011) provide evidence of the employment concentration across regions in Finland, which can be compared to Latvia. While Finland is considered to be a highly-clustered economy, and in almost all of its regions there is potential for cluster development and competitiveness (at least in some industries of the national economy), this is not the case in Latvia. Moreover, in Finland the degree of employment concentration in some industries and regions is two to four times greater (transportation, warehousing and communication) than the average level in the whole economy of Finland. In contrast, in only one Latvian region - Vidzeme - is the LQ in agriculture greater than 2 . At the same time, even in Finland, whose level of economic development is obviously higher than that of Latvia, some regions also specialize in the primary sector (LQ values vary from 1.26 to 1.98 ), while other industries with relatively high levels of employment concentration include mining, industrial production and energy (LQ values from 1.32 to 1.47); finances, ICT, business services (LQ from 1.25 to 1.56), which are also concentrated near the capital of the country; and transportation, warehousing and communications (LQ from 4.04 to 4.52) (Boronenko and Zeibote 2011). To resume the comparison, Latvia has a lower degree of employment concentration in certain economic activities than Finland. Nevertheless, Kemeny and Storper (2015) also point out that it is not a higher level of specialization that makes a region rich and developed, but the type of industry it specializes in - which may also partially explain why the Riga region is more economically developed than others. As a result, it is claimed that Latvia failed to distinguish highly competitive and export-oriented industries within its national and regional structures upon which to concentrate its efforts and resources, and to promote the further development of these industries - that is mentioned as one of the major causes of the deep recession in Latvia in 2008-2010 (Skribane and Jekabsone 2013). In addition, Skribane and Jekabsone (2013) note that the structure of the national economy of Latvia, which was spontaneously formed by private investors, does not result in the increase of economic competitiveness of Latvia.

The findings presented in this subsection disclose regional disparities and emphasize the necessity of the planned development of national and regional economic structures. However, to answer the main research question of the paper, the authors provide the results of the further analysis of income and its changes across regions and industries in the following section.

\subsection{Breakdown of income changes in Latvian regions}

Table 2 displays the results on the breakdown of the changes in real average income (see Subsection 3.2) by the type of economic activity and in the statistical regions of Latvia from 2008 to 2016. The results in Table 2 are based on the authors' calculations using data compiled from the Central Statistical Bureau of Latvia on the number of employees and income, with a breakdown by the type of economic activity and region.

First, the data in Table 2 display an absolute change in the average income in the regions from 2008 to 2016. Second, the applied method reveals the extent to which each industry contributes to the change in the aggregate income of the region. Furthermore, it also displays whether these changes in the aggregate income in a certain industry and/or region occurred due to changes in the average real income (the income component) or because of changes in employment shares (the employment component).

In Table 2, the highest increase of the real average income is in the Riga region (by 82.25 Euros), and the lowest in the Kurzeme region (36.47 Euros). This growth in the Riga region is mostly due to the high positive changes in two sectors, financial and scientific activities (K-N) and transportation and ICT $(\mathrm{H}, \mathrm{J})$, which add to the average income of this region 75.36 and 44.26 Euros, respectively. At the same time, the most negative impact is from construction $(F)(-37.16$ Euros), as well as industry and power engineering (BE), and public activities (O), (19.03 and 18.6 Euros respectively). These effects appear largely due to higher and/or negative changes in the employment share.

In the Pieriga region the same activities as those of the Riga region facilitated the growth of its average income in 2016, while the negative effect also appeared because of the decrease of income in construction $(F)$, public activities $(O)$, education $(P)$ and trade related activities $(G, I)$, which reduced the average income level in the region.

In the Vidzeme and Zemgale regions, agriculture (A) and industry and power engineering activities (BE) especially promote the increase of average income, which is principally due to the positive changes in the real average income (see also Figure 2). The reduction of the average income by public activities $(\mathrm{O})$ is also common for these regions. Furthermore, in Vidzeme, 
Table 2. Decomposition of the changes in the real average income by type of economic activity and statistical region of Latvia, in Euros

\begin{tabular}{|c|c|c|c|c|c|c|c|c|c|}
\hline $\begin{array}{l}\text { Type of } \\
\text { activity }\end{array}$ & $\begin{array}{c}\text { Income } \\
\text { component }\end{array}$ & $\begin{array}{l}\text { Employment } \\
\text { component }\end{array}$ & $\begin{array}{c}\text { Residual } \\
\text { component }\end{array}$ & $\begin{array}{l}\text { Total change in } \\
\text { the real average } \\
\text { income }\end{array}$ & $\begin{array}{l}\text { Type of } \\
\text { activity }\end{array}$ & $\begin{array}{c}\text { Income } \\
\text { component }\end{array}$ & $\begin{array}{c}\text { Employment } \\
\text { component }\end{array}$ & $\begin{array}{c}\text { Residual } \\
\text { component }\end{array}$ & $\begin{array}{c}\text { Total change } \\
\text { in the real } \\
\text { average } \\
\text { income } \\
\end{array}$ \\
\hline 1 & 2 & 3 & 4 & 5 & 1 & 2 & 3 & 4 & 5 \\
\hline \multicolumn{5}{|c|}{ Riga region } & \multicolumn{5}{|c|}{ Kurzeme region } \\
\hline (A) & 0.38 & 3.60 & 0.19 & 4.17 & (A) & 6.06 & -9.37 & -0.90 & -4.21 \\
\hline (B-E) & 20.56 & -33.11 & -6.49 & -19.03 & (B-E) & 23.86 & -19.57 & -4.14 & 0.16 \\
\hline$(\mathrm{F})$ & 4.86 & -38.15 & -3.87 & -37.16 & $(F)$ & 14.03 & -5.90 & -1.44 & 6.69 \\
\hline$(G, I)$ & 17.70 & -11.84 & -1.89 & 3.97 & $(\mathrm{G}, \mathrm{I})$ & 12.79 & 12.90 & 2.66 & 28.35 \\
\hline$(\mathrm{H}, \mathrm{J})$ & 17.54 & 24.09 & 2.64 & 44.26 & $(\mathrm{H}, \mathrm{J})$ & 12.92 & 7.15 & 1.15 & 21.22 \\
\hline$(\mathrm{K}-\mathrm{N})$ & 16.87 & 53.03 & 5.46 & 75.36 & $(\mathrm{~K}-\mathrm{N})$ & -17.32 & 17.53 & -4.99 & -4.78 \\
\hline (O) & -9.37 & -10.76 & 1.54 & -18.58 & $(\mathrm{O})$ & -2.60 & -17.56 & 0.96 & -19.19 \\
\hline$(\mathrm{P})$ & -5.79 & 13.07 & -1.19 & 6.10 & $(\mathrm{P})$ & -7.50 & 4.49 & -0.52 & -3.53 \\
\hline (Q) & -0.27 & 13.86 & -0.08 & 13.52 & (Q) & 0.48 & 9.74 & 0.13 & 10.35 \\
\hline (R-U) & 6.26 & 2.82 & 0.58 & 9.65 & $(\mathrm{R}-\mathrm{U})$ & 3.17 & -1.51 & -0.25 & 1.41 \\
\hline Total & & & & 82.25 & Total & & & & 36.47 \\
\hline \multicolumn{5}{|c|}{ Pieriga region } & \multicolumn{5}{|c|}{ Zemgale region } \\
\hline (A) & 4.20 & 1.02 & 0.10 & 5.32 & (A) & 18.40 & 16.13 & 3.53 & 38.06 \\
\hline (B-E) & 11.61 & 1.88 & 0.19 & 13.68 & $(B-E)$ & 21.55 & 3.37 & 0.63 & 25.55 \\
\hline$(\mathrm{F})$ & 8.36 & -22.88 & -3.23 & -17.76 & $(F)$ & 6.20 & -32.46 & -4.43 & -30.69 \\
\hline$(G, I)$ & 10.97 & -13.83 & -1.57 & -4.43 & $(G, I)$ & 19.26 & -1.46 & -0.43 & 17.37 \\
\hline$(\mathrm{H}, \mathrm{J})$ & 4.09 & 17.62 & 0.90 & 22.61 & $(\mathrm{H}, \mathrm{J})$ & 0.75 & 9.86 & 0.14 & 10.75 \\
\hline$(\mathrm{K}-\mathrm{N})$ & 13.32 & 29.54 & 4.65 & 47.51 & $(\mathrm{~K}-\mathrm{N})$ & 5.59 & 6.53 & 1.03 & 13.15 \\
\hline (O) & -3.44 & -9.27 & 0.47 & -12.24 & (O) & 1.31 & -11.19 & -0.26 & -10.15 \\
\hline$(\mathrm{P})$ & -5.42 & 0.39 & -0.03 & -5.06 & $(\mathrm{P})$ & -11.55 & 6.57 & -1.16 & -6.14 \\
\hline (Q) & 0.27 & 4.08 & 0.03 & 4.38 & (Q) & -1.84 & 15.40 & -0.66 & 12.90 \\
\hline$(\mathrm{R}-\mathrm{U})$ & 4.71 & -2.24 & -0.37 & 2.09 & $(\mathrm{R}-\mathrm{U})$ & 3.14 & -7.00 & -1.64 & -5.49 \\
\hline Total & & & & 56.10 & Total & & & & 65.31 \\
\hline \multicolumn{5}{|c|}{ Vidzeme region } & \multicolumn{5}{|c|}{ Latgale region } \\
\hline (A) & 23.59 & -0.24 & -0.07 & 23.28 & (A) & 17.34 & -3.04 & -0.93 & 13.38 \\
\hline$(B-E)$ & 13.69 & 4.95 & 0.69 & 19.34 & $(B-E)$ & 9.31 & -12.39 & -1.47 & -4.55 \\
\hline (F) & 10.44 & -4.86 & -0.89 & 4.69 & $(\mathrm{~F})$ & 2.61 & -12.57 & -1.00 & -10.96 \\
\hline$(G, I)$ & 13.47 & -13.45 & -3.37 & -3.36 & $(G, I)$ & 14.69 & 2.99 & 0.99 & 18.67 \\
\hline$(\mathrm{H}, \mathrm{J})$ & 2.68 & 4.35 & 0.26 & 7.29 & $(\mathrm{H}, \mathrm{J})$ & 13.70 & 1.53 & 0.48 & 15.71 \\
\hline$(\mathrm{K}-\mathrm{N})$ & 6.76 & -5.39 & -1.39 & -0.02 & $(\mathrm{~K}-\mathrm{N})$ & 7.27 & 13.21 & 3.25 & 23.74 \\
\hline (O) & -1.04 & -3.31 & 0.06 & -4.29 & $(0)$ & -4.51 & -18.27 & 1.44 & -21.34 \\
\hline (P) & -8.59 & 9.32 & -1.17 & -0.45 & (P) & -9.76 & 9.77 & -1.26 & -1.25 \\
\hline (Q) & -2.90 & 17.29 & -1.06 & 13.32 & (Q) & -1.35 & 11.73 & -0.33 & 10.05 \\
\hline$(R-U)$ & 3.66 & 1.62 & 0.32 & 5.60 & $(R-U)$ & 4.04 & 1.91 & 0.50 & 6.45 \\
\hline Total & & & & 65.40 & Total & & & & 49.90 \\
\hline
\end{tabular}

Source of raw data for authors`calculations: Central Statistical Bureau of Latvia (accessed in 2017)

the activities related to trade $(G, I)$, as well as financial activities (K-N) and education (P) also display a negative impact, while in Zemgale those with a negative impact are construction $(\mathrm{F})$ and education $(\mathrm{P})$ (with a high negative effect from its employment component, rather than its income component) and other services (R-U).

In the Kurzeme and Latgale regions an increase in the average income is mainly connected with trade and related activities (G, I). In Kurzeme, which is considered a transportation and storage junction, activities related to transportation $(\mathrm{H}, \mathrm{J})$ significantly added to positive changes in average income, while in the Latgale region this was the case for the finance sector (K-N). Changes within activities related to the public sphere $(\mathrm{O})$ and education $(\mathrm{P})$ had a negative impact, as in other regions. Furthermore, in the Latgale region, construction $(F)$ and, to a lesser degree, industry and power engineering $(B-E)$, reinforce the negative impact on the average income in the region, while in the Kurzeme region a negative result arose from agriculture $(A)$ and financial and related activities $(K-N)$.

The three main sectors that most negatively impact changes in the average income in the regions are 
activities related to the public sphere $(\mathrm{O})$, education $(\mathrm{P})$ and construction (F). The explanation might be that the research period involves the year 2008 - the beginning of the economic downturn in 2008-2010. For Latvia, this was a period of sharp decline in internal demand and income, resulting in extensive reforms in the public sector, and followed by a transformation of the education system, partially because of a decrease in the population (Kamola, Ivanova, and Kamols 2016). On the other hand, due to extensive budget reforms during the crisis of 2008-2010, the contraction of income in the public sector in Latvia was the largest, in comparison with the other Baltic states, though the decrease in income in construction was comparatively more modest than in Lithuania and Estonia, it nevertheless resulted in a substantial employment cuts in this sector (Masso and Krillo 2011).

\subsection{Comparison of income by industry in Latvian regions}

In this section, the authors further analyze changes in the real average income across Latvian regions in order to find out whether a shift of employees took place towards high-income, low-income, or both types of industries, and hence making an impact on regional differentiation. We first analyze the changes in average income and employment shares by industry. The results are presented in Figure 1.

During the period researched, the real average income increased in those economic activities where the regions have relative employment specialization or positions close to specialization (except Latgale, where growth was observed only in agriculture). These results are coincident with evidence from the US economy (Kemeny and Storper 2015), where findings display a positive relationship between employment specialization and income.

Figure 1 displays that in all types of economic activities across all Latvian regions the average income has increased since 2008, except the three sectors related to the public sphere $(\mathrm{O})$, education $(\mathrm{P})$ and health and social work activities (Q). On the one hand, the increase of income is positive. On the other hand, it is necessary to compare, first, the level of income in a certain industry with the average income at the regional level and, second, with the average income in this sector at the national level (see Figure 2).

Figure 2 displays that only in the Riga region is the average income in all economic activities higher than the average of the country. This is unsurprising because the Riga region is the most developed region in Latvia. In other regions, the average income in

Figure 1. Absolute changes in employment shares (horizontal axis, in \%p) and relative changes in real average income (vertical axis, in \%) in Latvian regions from 2008 to 2016
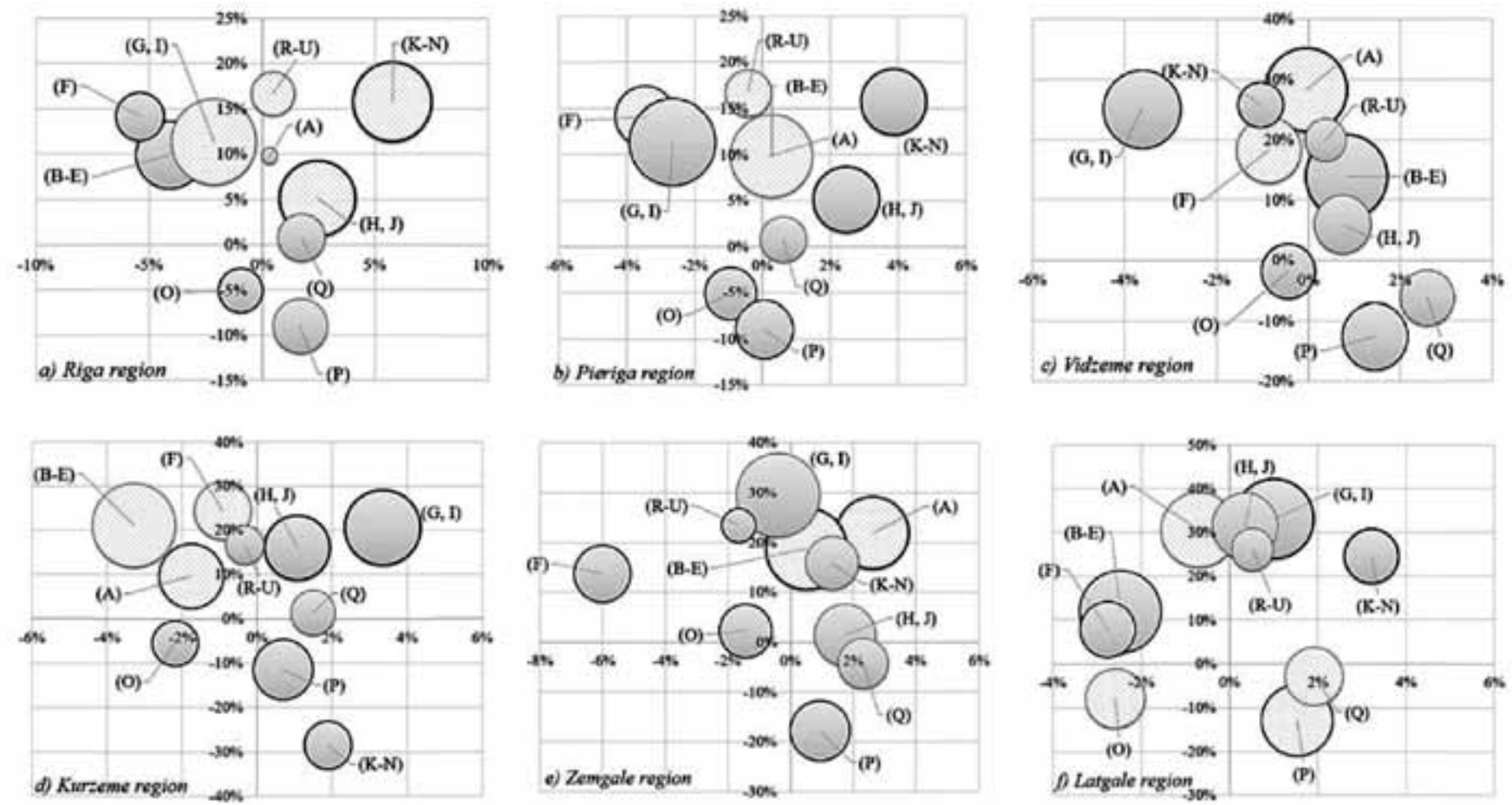

Source of raw data for authors`calculations: Central Statistical Bureau of Latvia (accessed in 2017)

Pattern fill - specialization of a region; Dark border - negative impact on the changes in the average income in a region; Thick grey border highly positive impact on the changes in the average income in a region; Size of bubbles represents employment shares in 2016. 
Figure 2. Comparison of the real average monthly income (average wage) within 10 types of economic activities in Latvian statistical regions, 2016

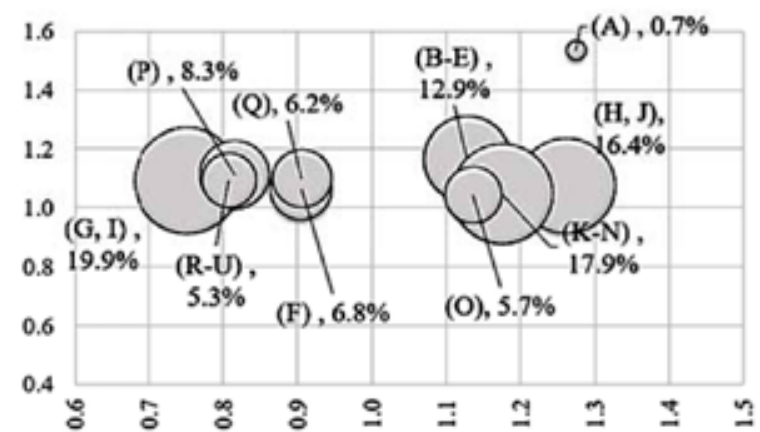

a) Riga region, average w. $874 \epsilon$
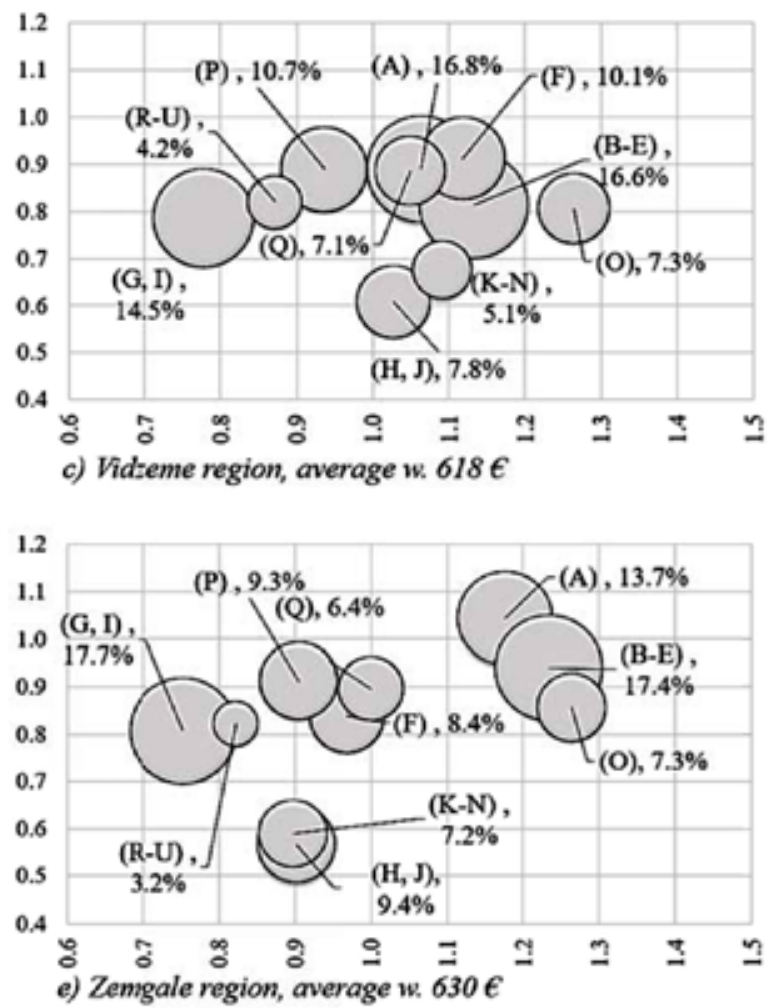

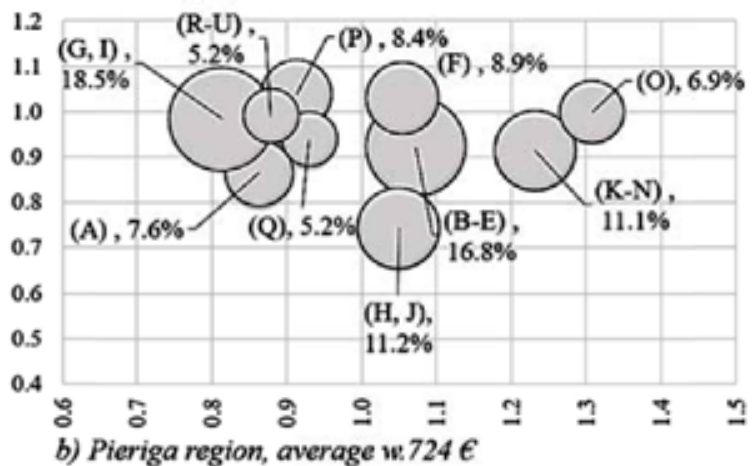

b) Pieriga region, average w. $724 \epsilon$
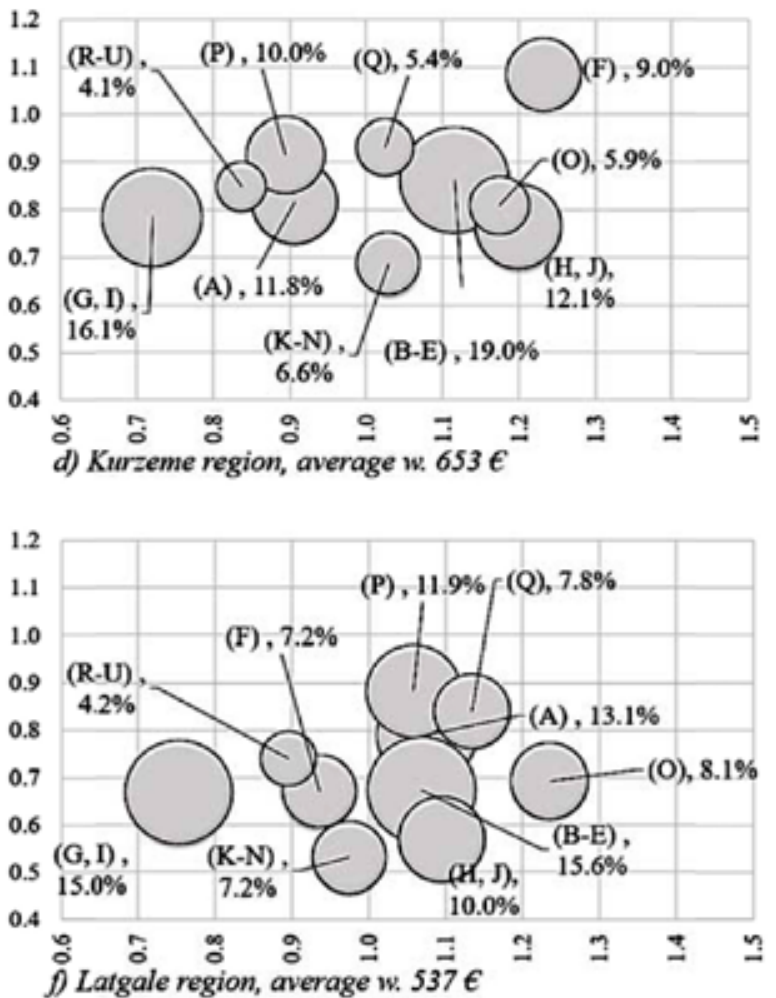

Source of raw data for authors`calculations: Central Statistical Bureau of Latvia (accessed in 2017)

Values on the horizontal axis represent a comparison with the average regional income level, while on the vertical axis - a comparison with the national average income level in a certain economic activity; The size of bubbles represent employment shares in 2016.

different types of economic activity is lower than the average national level in the same type of economic activity. However, there were also observed some economic activities where income is higher than that of regional as well as national levels, for example, in the Pieriga region (construction $(\mathrm{F})$, public administration, defence, and compulsory social security $(\mathrm{O})$ ), the Kurzeme region (construction (F) - based on data from the Central Statistical Bureau of Latvia, many construction-related enterprises come from this region, i.e. are registered there), and the Zemgale region (agriculture $(A)$ - based on data from the Latvian Rural Advisory and Training Centre; Zemgale is the most productive land in Latvia).
Furthermore, regarding employment concentration and the average income level, in those economic activities where regions have employment specialization or positions near specialization, the average income is generally higher than the average income in the region, with some exceptions in the Riga region (trade related activities $(G, I)$ and other services $(\mathrm{R}-\mathrm{U})$ ), Pieriga (agriculture $(A)$ and other services $(R-U)$ ), and Kurzeme (agriculture (A)).

Moreover, in the Riga region almost $54 \%$ of all employees in the region receive an income that is higher than the average of the region, in Pieriga - almost $55 \%$, in Vidzeme - almost $71 \%$, in Kurzeme - about $58 \%$, in Zemgale - almost $45 \%$, and in Latgale - about 
$67 \%$. But it should be noted that in certain regions a large part of economic activities are low income activities (wage dispersion in Latvia is one of the highest across the EU (Magda et al. 2011)).

The results obtained in this research regarding the income differences between the industries of national and/or regional economies are consistent with evidence from Eastern and Western Europe - notable wage differences exist across industries of a national economy (Magda et al. 2011; Du Caju et al. 2010). In addition, Magda et al. (2011) and Du Caju et al. (2010) agree that the industries with the highest income are similar across European countries and are related to oil and gas extraction, nuclear power, chemicals, mining and quarrying, production and distribution of electricity/gas/water, air transport, finances and ICT, while the industries with the lowest income are traditional industries, including among others the clothing industry, woodwork, as well as trade, hospitality and catering activities. In Latvia, low-income industries (see Figure 2), in which the average income is below the average regional level, also include trade, hospitality and catering activities $(G, I)$, as well as education $(P)$ and other services (R-U), which are marked out particularly in all regions. Moreover, there is some evidence that the ranking of the best-worst paid industries remains persistent over time (Du Caju et al. 2010). The fluctuations of income level differences between industries vastly vary across European countries: they are more concentrated in such developed countries as Norway and Belgium, while, for example, in Latvia, Lithuania and Slovakia, dispersions are the highest (Magda et al. 2011). Therefore, this partly explains the substantial regional differentiation between Riga and other regions in employment distribution. Applying efforts to reducing these differences may help to lower regional differentiation.

Comparison of the data from Figure 1 and Figure 2 reveals that not all employment shifts between economic activities are towards employment types that provide higher income. Expanding the comparison to industries which demonstrated positive changes in the employment shares and where the average income increased within low- and high-income activities across regions, it becomes evident that during the research period in the Riga and Pieriga regions the shifts occurred not only towards high-income industries but also towards low-income activities. For more developed regions such a shift of employees may not have a large negative effect. At the same time, those regions that are below the average level of development may deteriorate even more. However, in the long run, such shifts may result in rather negative consequences, even for economically developed regions.
The case in point are two regions of the USA. During the majority of the twentieth century, the Los Angeles region had the highest performing economy, while today, in terms of income, it is outpaced by a third by San Francisco. Therefore, Makarem, Storper and Kemeny (2015) claim that in order to promote development and to minimize regional differentiation it is necessary to engage in the "new economy" - to attract and support new high-cost and high-wage industries rather than develop and maintain low- and mediumwage jobs.

\section{CONCLUSION}

The findings obtained reveal an evident economic disparity between the Riga region and other statistical regions of the country, which remains rather persistent over time and one of the highest across the European Union. Furthermore, the structure of the national and regional economies has a negative impact on regional differentiation in the statistical regions of Latvia.

The analysis of employment distribution showed that employment specialization varied between Latvian regions during the period researched. According to the obtained results, the most characteristic employment specialization areas in the Latvian economy in general are agriculture, forestry and fishing (A), manufacturing, mining and quarrying, energy (B-E), and construction (F).

Riga region stands distinctly ahead of the other regions, with the highest rate of specialization in financial, trade and transportation activities. In addition, during the research period its regional specialization remained stable, showing only slight changes. In comparison to a more developed country, differentials appear in the level of specialization - Latvian regions did not reveal a rather strong level of specialization, which also may lower further development prospects; however, it also depends on which type of economic activity the region specializes in.

The results of the decomposition of changes in the received income revealed that mainly three sectors negatively impacted the changes in the average income level in Latvia - the activities related to the public sphere $(\mathrm{O})$, education $(\mathrm{P})$ and construction $(\mathrm{F})$, which appeared to be more exposed to changes in economic conditions. While the largest positive effect of economic activities varied across regions, it was mainly related to agriculture $(A)$ and industry and power engineering (B-E), or trade-related activities (G, I) in the less-developed regions. However, in the Riga and Pieriga regions it was largely connected with activities related to finance (K-N), transportation and ICT 
activities $(H, J)$, activities that were typical of the central regions.

In addition, in the Latvian statistical regions, the least financially-rewarding sectors were related to trade activities $(G, I)$, education $(P)$, and other services $(\mathrm{R}-\mathrm{U})$. These findings are partly in line with the results obtained in previous research.

Overall, during the researched period the regions mainly specialized in low-value-added activities, such as agriculture, which could facilitate neither regional development nor the growth of the population's income. On the other hand, the real average income slightly increased in these industries, and the average income in such industries was generally higher than the average level in the region. Nevertheless, in some regions, a large part of economic activities was insufficiently paid for, which could not promote the further development of the region. Furthermore, it should be noted that not all shifts of employees between economic activities are towards better-paid job types; some are also towards worse-paid job types. For the regions that are below the average level of development this may allow the situation to deteriorate further, while for such well-developed regions as Riga, over a short-term period, such shifts of employees may not have a large negative effect.

The authors conclude that the main purpose of this research, namely to find out whether changes in employment structure have an impact on regional differentiation, was achieved. The applied method of comparative statistical analysis allowed the authors to conduct the research, and the obtained results indicate that changes in the employment structure influenced regional differentiation in Latvia during the period researched.

Nevertheless, in further research it is necessary to analyze to a greater degree whether it is possible to reduce regional disparities by implementing structural changes, and which factors can facilitate this and to what extent. A more detailed analysis of the structure of national economy and the reasons for people's preferences for certain types of economic activities is recommended.

\section{REFERENCES}

Boronenko, V., and Zeibote, Z. 2011. 'The Potential of Cluster Development and the Role of Cluster Support Policies in Latvia'. Economic Annals 56 (191): 35-67. doi:10.2298/ EKA1191035B.

Caju, Ph. Du, Katay, G., Lamo, A., Nicolitsas, D., and Poelhekke, S. 2010.'Inter-Industry Wage Differentials in EU Countries: What Do Cross-Country Time Varying Data Add to the
Picture?' Journal of the European Economic Association 8 (2-3): 478-86. doi:10.1162/jeea.2010.8.2-3.478.

Central Statistical Bureau of Latvia. 2017. Statistics Database. Retrieved from: http://www.csb.gov.lv/en/dati/statisticsdatabase-30501.html

Clark, C. 1940. The Conditions of Economic Progress. 1st ed. London: Mcmillan.

Cross-sectoral Coordination Centre. 2013. 'National Development Plan of Latvia for 2014-2020'. 'Latvijas Vēstnesis'. http://www.pkc.gov.Iv/sites/default/files/inline-files/NDP2020 English Final_.pdf.

Dietrich, A. 2012. 'Does Growth Cause Structural Change, or Is It the Other Way around? A Dynamic Panel Data Analysis for Seven OECD Countries.' Empir Econ 43: 91544. doi:10.1007/s00181-011-0510-z.

Dinc, M. 2002. 'Regional and Local Economic Analysis Tools'. World Bank Institute. Washington DC: The World Bank.

Fisher, A. 1939. 'Production, Primary, Secondary, and Tertiary'. Economic Record 15: 24-38. doi:10.1007/978-1-4614-1380-6.

Fourastié, J. 1954. Die Große Hoffnung Des 20. Jahrhunderts. ('The Great Hope of the 20th Century'). Köln-Deutz.

Fracasso, A., and Vittucci Marzetti, G. 2017. 'Estimating Dynamic Localization Economies: The Inadvertent Success of the Specialization Index and the Location Quotient'. Regional Studies, no. December 2016: 1-14. do i:10.1080/00343404.2017.1281388.

Gokan, T. 2010. 'On the Usage of the Measurements of Geographical Concentration and Specialization with Areal Data'. In Spatial Statistics and Industrial Location in CLMV: An Interim Report, edited by Ikuo Kuroiwa. IDE-JETRO.

Havlik, P. 2005. 'Structural Change, Productivity and Employment in the New EU Member States'. Wiiw Research Reports. The Vienna Institute for International Economic Studies.

Kamola, L., Ivanova, S., and Kamols, U. 2016. 'Trends of Regional Development in Latvia - Aspect of Human Resource'. In Proceedings of 13th Research World International Conference, 4:21-25. Khandagiri, Bhubaneswar.

Keller, R. 2009. 'How Shifting Occupational Composition Has Affected the Real Average Wage'. Monthly Labor Review, no. June: 26-38.

Kemeny, T., and Storper, M. 2015. 'Is Specialization Good for Regional Economic Development?' Regional Studies 49 (6): 1003-18. doi:10.1080/00343404.2014.899691.

Krüger, J. 2008. 'Productivity and Structural Change: A Review of the Literature'. Journal of Economic Surveys 22 (2): 330-63. doi:10.1111/j.1467-6419.2007.00539.x.

Kutscherauer, A., Fachinelli, H., Hucka, M., Skokan, K., Suchacek, J., Tomanek, P., and Tuleja, P. 2010. 'Disparities in Country Regional Development - Concept, Theory, Identification and Assessment'. Regional Disparities in 
Regional Development of the Czech Republic. Ostrava:VŠBTechnical University of Ostrava, Faculty of Economics. do i:10.1177/0020881787024003002.

Kuznets, S. 1973. 'Modern Economic Growth: Findings and Reflections'. American Economic Review 63 (3): 247-58. doi:10.2307/1914358.

Magda, I., Rycx, F., Tojerow, I., and Valsamis, D. 2011. 'Wage Differentials across Sectors in Europe: An East-West Comparison'. Economics of Transition 19 (4): 749-69. doi:10.1111/j.1468-0351.2011.00417.x.

Makarem, N., Storper, M. and Kemeny, T. 2015. The Rise and Fall of Urban Economies: Lessons from San Francisco and Los Angeles. Stanford, CA: Stanford University Press.

Masso, J., and Krillo, K. 2011. 'Labour Markets in the Baltic States during the Crisis 2008-2009: The Effect on Different Labour Market Groups. 79. The University of Tartu Faculty of Economics and Business Administration Working Paper. Tartu.

McMillan, M., Rodrik, D., and Sepúlveda C., eds. 2016. Structural Change, Fundamentals, and Growth: A Framework and Case Studies. Washington DC: International Food Policy Research Institue (IFPRI). doi:http://dx.doi.org/10.2499/9780896292147.

Melihovs, A., and Kasjanovs, I. 2011. 'The Convergence Processes in Europe and Latvia'. Discussion Papers. Latvijas Banka.

Mihnenoka, A., and Saulītis, J. 2013. 'Evaluating the Significance of Structural Changes within National Economy for Economic Growth of Latvia Using the Econometric Model.' Economics and Business 23: 62-70.

Mikulić, D., Lovrinčević, Ž., and Nagyszombaty, A. G. 2013. 'Regional Convergence in the European Union, New Member States and Croatia'. South East European Journal of Economics and Business 8 (1): 9-21. doi:10.2478/ jeb-2013-0001.

MPS Task Force of the ESCB. 2004. 'Sector Specialisaiton in the EU: A Macroeconomic Perspective'. ECB Occasional Paper Series.

O'Leary, E., and Webber, Don J. 2015. 'The Role of Structural Change in European Regional Productivity Growth'. Regional Studies 49 (9): 1548-60. doi:10.1080/00343404 .2013.839868.

Peneder, M., Kaniovski, S., and Dachs, B. 2003. 'What Follows Tertiarisation? Structural Change and the Role of Knowledge-Based Services'. The Service Industries Journal 23 (2): 47-66. doi:10.1080/02642060412331300882.

Peneder, M.2009.Sectoral Growth Drivers and Competitiveness in the European Union. European Communities. doi:10.2769/55360.

Poledníková, E., and Lelková, P. 2012. 'Evaluation of Regional Disparities in Visegrad Four Countries, Germany and Austria Using the Cluster Analysis'. In XV. International Colloquium on Regional Sciences: Valtice, 20 to 22 June 2012, 36-47. Valtice: Masaryk University.
Sayago-Gomez, J. T., and Stair, C. 2015. 'Location Quotient,Coefficient of Specialization and Shift-Share'. Working Papers. Technical Document Series.

Silva, E., and Teixeira, A. 2008. 'Surveying Structural Change: Seminal Contributions and a Bibliometric Account'. Structural Change and Economic Dynamics 19 (4): 273300. doi:10.1016/j.strueco.2008.02.001.

Šipilova, V. 2012. 'Structural Changes in Gross Domestic Product in Latvia Quantitative and Qualitative Aspects'. In Proceedings in EIIC - 1st Electronic International Interdisciplinary Conference, 290-96. EDIS - Publishing Institution of the University of Zilina.

_-_. 2013. 'Human Capital, Education and the Labor Market: Evaluation of Interaction in Latvia'. In Procedia - Social and Behavioral Sciences, 106:1384-92. doi:10.1016/j.sbspro.2013.12.154.

Šipilova, V., and Baldi, G. 2013. 'On the Structural Composition of Latvia's Economy: A Detailed Account of Its Specialization and Regional Differentiation'. Regional Review, no. 9: 5-15.

Skribane, I., and Jekabsone, S. 2013. 'Structural Changes in the Economy of Latvia after It Joined the European Union'. Intellectual Economics 7 (1): 29-41.

Stiglitz, J. E. 2011.'Rethinking Macroeconomics: What Failed, and to How Repair It'. Journal of the European Economic Association 9 (4). Blackwell Publishing Inc: 591-645. doi:10.1111/j.1542-4774.2011.01030.x.

Stojčić, N., Bezić, H., and Galović, T. 2016. 'Economic Structure and Regional Economic Performance in Advanced Eu Economies'. South East European Journal of Economics and Business 11 (1): 54-66. doi:10.1515/jeb-2016-0004.

Tvrdoň, M., and Skokan, K. 2011. 'Regional Disparities and the Ways of Their Measurement:The Case of the Visegrad Four Countries'. Technological and Economic Development of Economy 17 (3): 501-18. doi:10.3846/20294913.2011.6 03485.

Vanags, A., Basarova, J., and Titova, N. 2002. 'Industrial and Intellectual Capital Clusters in the Baltic States'. In 42nd Congress of the European Regional Science Association: 'From Industry to Advanced Services - Perspectives of European Metropolitan Regions'. Dortmund.

Wishlade, F., and Yuill, D. 1997. 'Measuring Disparities for Area Designation Purposes: Issues for the European Union'. Regional and Industrial Policy Research Paper. Glasgow : European Policies Research Centre.

Wolfe, M. 1955. 'The Concept of Economic Sectors'. The Quarterly Journal of Economics 69 (3): 402-20. doi:10.2307/1885848.

Wölfl, A. 2005. 'The Service Economy in OECD Countries'. The Service Economy in OECD Countries. Vol. 3. doi:10.1787/212257000720. 